\title{
A holistic view of the Holy Spirit as agent of ethical responsibility: This view experienced as exciting in Romans 8, but alarming in 1 Corinthians 12
}

\author{
E J Vledder \& A G van Aarde \\ University of Pretoria
}

\begin{abstract}
Modern man experiences a crisis which manifests itself across a wide spectrum: ecologically, sociologically and politically. Seen from a holistic perspective, this crisis, caused by the so-called mechanical worldview, calls for a radical change to a new worldview, the so-called postmodern or holistic view. In ecumenical theology, emphasis is also laid on the world in crisis, which calls for renewal on the same levels as in holistic thought. This change and renewal is to be brought about by the Holy Spirit, who is the agent of change in thought, and of involvement in creating a 'new creation'. It will be argued that the Holy Spirit is indeed involved as the agent of man's ethical responsibility; in Romans 8:1-17 this is seen as exciting, but, in 1 Corinthians 12:1-11, the alarming danger in ecumenical pneumatology is indicated.
\end{abstract}

\section{Das Echtheitszeichen des Heiligen \\ Geistes is allein das Bekenntniß: \\ Kyrios Jesus [1 Kor 12, 3].}

(Bornkamm 1983:188)

\section{INTRODUCTION}

The world is in a crisis. This crisis is experienced on sociological, health, economical, technological, political and ecological levels (to name but a few). This crisis needs to be addressed. From a holistic perspective, this can only be done from a

Submitted in 1990 and accepted as part of the requirement for the MDiv degree, Faculty of Theo$\operatorname{logy}(\operatorname{Sec} A)$, University of Pretoria, under the guidance of prof dr A G van Aarde. Financial assistance from the Human Sciences Research Council for this study is hereby acknowledged. Opinions expressed in this research or conclusions drawn are those of the author, and not necessarily of the HSRC. 
change in worldview. This thought is taken over in ecumenical theology. Emphasis is laid on change in the world in crisis. This change is to be brought about by the Holy Spirit, who is the agent both of change in thought and of involvement in creating a 'new creation'.

The purpose of this paper is to give a short overview of postmodern holistic thought, in as far as it has found its way in ecumenical pneumatology. Therefore an overview will also be given of ecumenical pneumatology, with the emphasis on the Holy Spirit as the agent of change and of active ethical involvement in bringing about change. The role of the Holy Spirit as agent of change, as functioning in ecumenical pneumatology will then be evaluated from a few perspectives derived from Romans 8:1-17, 18-25, Galatians 5:13-26 and 1 Corinthians 12:1-11.

It will be argued that the holistic interpretation given to the Holy Spirit in ecumenical pneumatology holds exciting possibilities, because it reminds us of our ethical responsibility towards our environment. Yet, there is also a danger in ecumenical pneumatology: Such emphasis could be laid on social, political and ecological issues that pneumatology is loosened from its christological basis. This is experienced as alarming.

\section{HOLISM}

One of the most prominent themes in postmodern holistic thought is that the whole modern world is in a crisis. Capra (1983:xviii), one of the present-day exponents of holism, states: 'We have high inflation and unemployment, we have an energy crisis, a crisis in health care, pollution and other environmental disasters, a rising wave of violence and crime... This crisis is essentially a crisis of perception.' This crisis is mainly caused by the so-called mechanical or Newtonian-Cartesian worldview. 'It is this Newtonian-Cartesian paradigm of science, interpreted for the public by Francis Bacon's ideas about the necessity of regaining dominion over nature, which New Age thinkers [the semi-religious movement of holism; see Capra 1983:462; Van Aarde 1990:294 - E J V] declare is responsible for much of the damage both to the planetary environment and to the human psyche' (Wilkenson 1987:11). By this, man has become alienated from the earth. He has become an alienated observer instead of a participating inhabitant (Schoeman 1990:268).

The main purpose of scientific knowledge in mechanical thought, as reflected both by the rationalism of Descartes and the empirism of Bacon, is to gain unquestionable knowledge and to rule over nature. This goal can only be reached if the edifice of knowledge is built on a foundation of indubitable beliefs, be it empirical data [Bacon] or clear and distinct ideas [Descartes]' (Mouton \& Pauw 1988:179). The goal was to dominate nature and today science and technology are mainly used 
for purposes that are mainly anti-ecological (Capra 1983:40). This Newtonian-Cartesian paradigm proved to be inadequate to describe the world. It was first challenged in physics by Einstein's theory of relativity (Wilkinson 1987:12; see also Bohm 1986:19; Capra 1983:65). Because mechanical thought was regarded as 'spiritless materialism' (Wilkinson 1987:14), radical change to a new worldview, the socalled postmodern or holistic view was essential.

The universe is no longer seen as a machine which only has to be taken apart, but as an undivisible, dynamic whole whose parts are interrelated and can only be understood as patterns of a cosmic process. Quantum theory (one of the building stones of holism) makes it clear that the universe could no longer be analysed as independent, isolated elements. 'Whereas in classical mechanics the properties and behavior of the parts determine those of the whole, the situation is reversed in quantum mechanics: It is the whole that determines the behaviour of the parts' (Capra 1983:76; see also Bohm 1986:34; Martin 1987:371). Everything is seen as a whole, as an organism with its own internal organisation or structure. According to Smuts (1987:98), this applies to -, from the lowest micro-organism, to the more complex human personality. It applies to biological organisms (plants and animals) and to human institutions like the state. Smuts (1987:98) puts it as follows: 'In the view here presented "wholes" are basic to the character of the universe, and "Holism", as the operative factor, in the evolution of wholes, is the ultimate principle of the universe.' Bohm (1986:34) summarises this principle: 'The wholeness of the whole and the parts.'

Everything and everyone in the universe, like an organism, is interrelated to each other. An organism functions as a whole and any change in one of its elements, has an influence on the other as well as the whole (Van Arkel 1988:230). 'The new vision of reality we have been talking about is based on awareness of the essential interrelatedness and interdependence of all phenomena - physical, biological, psychological, social and cultural' (Capra 1988:285). Bohm (1986:34) states: 'Each human being is thus internally related to the totality, including nature, and the whole mankind [and he is therefore also internally related to other human beings].' Thus, there is an intrinsic balance between everything in the universe.

This balance could, however, be disturbed, and the inner relations broken, with an effect on everything else. According to Capra (1983:431-432), highly imbalanced sets of values have led to an overemphasis on hard technology, wasteful consumption, and rapid exploitation of natural resources, all motivated by the persistent obsession with growth. Undifferentiated economic, technological, and institutional growth is now causing ecological disasters, widespread corporate crime, social disintegration, and an ever-increasing likelihood of nuclear war. Therefore the time has 
come for man, as part of the whole universe, to become more actively involved in changing and improving the whole world. Destruction of the world means destruction of mankind. According to Hefner (1988:25-26), mankind should realise that he is 'God's co-creator'. Man is part of the creation process. He should discover his environment and take up his responsibility towards it (Hefner 1987:127). As cocreator he should use his technology and knowledge, not only to establish civilisation, but also to build and improve the future of the ecosystem (Hefner 1987:136). This active involvement in changing the world, and bringing it into balance again, is seen vitally important: 'To change this situation is now absolutely vital for our wellbeing and survival, and change will only be possible if we are able, as a society, to a new holistic and ecological vision of reality' (Capra 1989:193).

\section{ECUMENICAL PNEUMATOLOGY}

The theme for the Seventh Assembly of the World Council of Churches in Canberra, Australia, in 1991 was 'Come, Holy Spirit - Renew the whole creation'. Preceding this Assembly, a few of The Ecumenical Reviews (quarterly publications of the WCC) deal especially with the topic of the Holy Spirit. The Ecumenical Reviews, therefore, give a responsible overview of the pneumatology of the ecumenical movement, which is most suitable as a point of departure and evaluation. Vischer (1990: 143) mentions that up till now, the World Council has always given preference to Christological themes. 'It is odd, really, that the Holy Spirit has not figured as an assembly theme before now - for in a certain sense, the Spirit is the theme of the ecumenical movement. For how else but through the action of the Spirit could the divided churches ever find their way to unity?'

One of the most striking similarities with holistic thought (apart form the theme of unity) is that emphasis in ecumenical theology (and pneumatology) is also laid on the crisis in the world. Moltmann (1990:99) sees this crisis in the ecology, the annihilation of species (plants and animals), the increase in human population, injustice and violence. As Tinker (1989:527) puts it: 'We are destroying God's creation at such an alarming rate, polluting the earth's waters and air, and at the same time inventing ever new and ever more brutal ways to oppress greater and greater portions of the earth's human population...' (see also Assmann 1990:50; Lechte 1990: 157; Tamez 1989:446-447). This is a clear indication of holistic influence in ecumenical pneumatology.

The crisis, as in holism, needs to be addressed. Whereas in holistic thought change to a new paradigm is seen as something spontaneous, in ecumenical thought this is to be brought about by the Holy Spirit. In holism, change cannot be stopped. It will happen all by itself. Boelema (1987:4) calls it a 'zachte culturele revolutie'. 
Capra (1983:16), quoting from the Chinese I Ching, describes change as: 'The movement is natural, arising spontaneously. For this reason the transformation of the old becomes easy. The old is discarded and the new is introduced....'

In ecumenical pneumatology however, emphasis is laid on the Holy Spirit who should make man aware of his responsibility towards the world and towards change and the renewal of creation. On who the Spirit is, we are not too sure. Flessemanvan Leer (1989:348) says that the Spirit is a vague and hazy concept, difficult to define. To define the Spirit one cannot simply reel off the biblical passages to give a clear picture of where the right Spirit lives or who he is (Schweizer 1989:406). But, although not clearly definable, we can see the Spirit at work (Bobrinskey 1989:359). Schweizer (1989:413) neatly wraps it up by saying: 'If we try to sum up what is central in the New Testament despite all the differences, we can see that in it there is no doctrine on the Spirit, but rather that the Spirit is narrated as an event - as happening.' It is not who he is that counts, but what he does. And what does he do? Arguing from Romans 8:12-17, Schweizer (1989:408) answers:

The Spirit bestows on those who are 'fellow heirs with Christ' the Spirit of sonship and in that sonship the call to God as Father. Precisely by this the Spirit also makes them sensitive to the sufferings of creation and their hope of the glory which will one day be theirs holds good for the creation too [8:18-27]. But it is the Spirit that is at work in believers...It can be said, then, that the Spirit bestows on the Christian community a solidarity with the suffering creation and makes them able to hear clearly that God has purpose for it too. But this is the Spirit of Christ bestowed on the community (my italics).

This view of Schweizer is shared by a number of exponents of ecumenical pneumatology. The Holy Spirit is the agent of renewal: 'In the Acts of the Apostles the Holy Spirit functions as a supernatural power that alters, works through and directs believers... With the dramatic experience of Pentecost, the disciples were transformed into a confident and dynamic group, not afraid to proclaim and live out their faith in Jesus as Messiah' (Osei-Bonsu 1989:457).

The Holy Spirit is the power to change attitudes and life-styles. He moves all people to formulate ethical norms and abide by them. He is the one who moves the believer (but also the whole world) to a 'new life'. But how is this 'new life' or 'renewal' interpreted in ecumenical pneumatology?

Renewal by the Holy Spirit is given a cosmological interpretation. This means that renewal does not just mean emotional piety, but the creation of a 'new creation' 
in the 'new things' which are happening in the world around (see Lemopoulos 1989: 464). Renewal involves almost everything, not only a new heaven but also a new earth (Matsoukas 1989:399). It involves the whole world, or whole creation, or 'mother earth' and everything on it. As Tinker (1989:532) puts it: 'We are all relatives: from buffaloes and eagles to trees and rocks, mountains and lakes' (see also Schaeffer 1990:66-67). In this we clearly see holistic traces.

Thus, renewal is seen in a very broad sense: "By "renewal"...I understand any act or process whereby the Holy Spirit intervenes in the lives of believers to transform, invigorate and regenerate the human condition of creation as a whole. I take "crea-

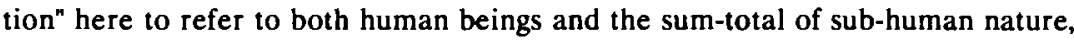
animate and in-animate' (Osei-Bonsu 1989:454). Thus the Holy Spirit is interpreted as the liberating power in the political, sociological and environmental (ecological) sense (see Raiser 1989:382). It is especially Rosato (1989:393-394) that takes up this thought and works it out. In his paragraph entitled 'The Spirit as liberator: Renewing the justice of the church and the moral energy of humanity', Rosato emphasises the identity of the Holy Spirit as Spiritus Liberator when arguing from Galatians 5:25. The Spirit is the one that serves 'to highlight the irrefutable responsibility Christians have to promote moral values, so that the development of the temporal order might reflect the truth and the love offered to humanity by the divine Pneuma'. The Spirit is the renewal of moral strength, and these moral values are articulated in purely socio-economic terms. These values are extended even beyond the church, into society. As Rosato (1989:394) states:

Yet most of the churches do recognize that, in definitely withstanding the power of banks, parliaments and armies which jointly suppress human rights..., Christians are frequently supported by those who do not believe in Christ...Clearly, the motivations which underlie this concerted protest differ substantially: Christians ground their moral power and political resistance in their faith that the Holy Spirit stands on the side of righteousness....

It is clear that personal ethics thus finds its place in social ethics. Human beings thus become fellow-workers with God. 'Human beings become creators; they conquer fear and selfishness by believing in the work of the Holy Spirit' (Matsoukas 1989:404). Therefore, moral values and ethical issues, as already indicated, are interpreted very specifically in Preston's (1989:562) terms: the introduction of new technology and techniques for education, environmental issues, treatment of animals in teaching, research and zoos, and responsibility for future generations. It 
should lead to 'love for those who experienced condemnation, oppression, famine, nakedness, persecution, perils, the sword' (Tamez 1989:449). It should take us to act against the destruction of the environment, not only for the sake of survival (as Capra and holistic thought suggests), but also because we are moved to it by the Holy Spirit.

\section{ON EVALUATING THE HOLISTIC INTERPRETATION OF THE HOLY SPIRIT IN ECUMENICAL PHEUMATOLOGY}

\subsection{The 'exciting' experience}

It has already been mentioned above that a clear definition of the Holy Spirit is not easily available in the New Testament. We do not thus intend discussing in detail who the Spirit is, and what he does. Yet one aspect stands out quite prominently in the literature on the Spirit, as well as in the reflections on Paul's view of the Spirit: the Spirit is seen as the 'Power of God'. Schütz (1985:163) uses the expression

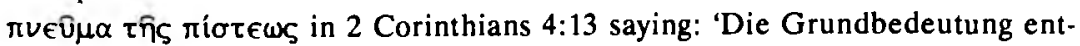
sprechender paulinischer Wendung ist die von Geist als Gotteskraft.' The Spirit is characterised as the one that brings man to believe and to let him live as believer. As Schütz (1985:163) states: 'Der Geist ist demnach die Glauben schaffende, zum Glauben rufende und Glauben ermöglichende Gotteskraft [vgl. Gal 3,14; 1 Kor 12,9].'

It is especially in the context of the so-called 'spirit-flesh' dualism that the Spirit as the power of God is properly understood. Schütz argues that $\pi v e v \mu \alpha$ is used as renunciation ('Absage') of the ox́p. The Spirit in this context indicates a power under which the believer lives ( $\mathrm{Rm} \mathrm{8:4;} \mathrm{Gl} \mathrm{5:17ff).} \mathrm{It} \mathrm{reveals} \mathrm{the} \mathrm{redemptive} \mathrm{activi-}$ ties of God to the believer; it establishes the new life; it signifies the objective power of the divine promise of grace that this new life produces; it places the believer under a strong promise: 'Das Pneuma erweist sich als diejenige Kraft, die die ganze Existenz der Glaubenden als die eines aus dem Christusereignis Lebenden bestimmt.' The Spirit stands against the 'sarx' which indicates man's own powerlessness, man's emnity with God (Rm 5:6ff; 8:7), or as Knoch (1975:53) puts it:

Die Grundeinstellung des gefallenen Menschen gegen Gott ist Selbsverschließung, Selbstgerectigkeit, Selbstverweigerung, die zu Gleichgültigkeit, zu Ungehorsam, Empörung und Abfall führen. Diese Grundhaltung des gefallenen Menschen, der selbst dann nicht dem Willen Gottes auf rechte Weise zu entsprechen vermag, wenn er dies will, bezeichnet Paulus mit dem Wort Fleisch, sarx. 
By 'flesh' Paul means all human behaviour, 'or more precisely all human life which looks for salvation to its own frantic efforts' (Schweizer 1980:84). 'Flesh' indicates the total alienation between man and God because of man's falling into sin (see $\mathrm{Rm}$ 7:14, 18; 8:4; 2 Cor 10:2; 11:18, Gl 5:16, 24; 6:12; Phlp 3:3). The 'fleshly' man stands against God and his will, or against his Spirit (Knoch 1975:54).

In this context, according to Schütz (1985:164), the Spirit signifies the way, the norm, or way of living that is 'the life according to the Spirit' (see Rm 8:4; Gl 5:16, 25).

By 'Spirit' Paul means the action of God himself, which man experiences as a gift that comes upon him and makes him happy, sets him free and makes his life responsible and meaningful...'Spirit' is God himself at work granting us life and service...Spirit is the only power that can achieve anything, for it is the power of God himself...The Spirit of God is the real power, for the Spirit is God himself at work within us.

(Schweizer 1980:84-85)

It is against this background that we can go forward to investigate a few specific passages in which the Spirit is discussed. Romans 8:1-25 is chosen because of its frequent use in ecumenical pneumatology (see Flesseman-van Leer 1989:355; Hübner 1989:329; Moltmann 1990:98; Rosato 1989:393; Schweizer 1989:408; Schaeffer 1990: 67; Tamez 1989:446). It might also spread some light on the aspect of the Spirit as agent of ethical involvement. A remark by Heron (1983:46) in this regard is quite appropriate: 'The sheer range of the Spirit's scope and activity is especially apparent in Paul's most extensive portrayals in Rom. 8:1-27 and Gal. 5:15-26: everything from justification to the final manifestation of the children of God, from faith to prayer, from ethical behaviour to calling God, "Abba! Father!", is enabled by the Spirit' (my italics).

Romans 8:1-17 must be seen against the background of Romans 7:14-25. Schlier (1979:228) sums up Romans 7:14-25 as '[d]ie Situation des unter die Sünde verkauften Menschen', which has its climax (see Du Plessis 1969:18) in Paul's la-

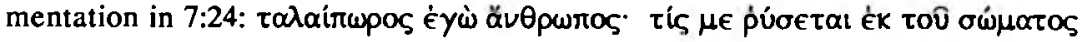

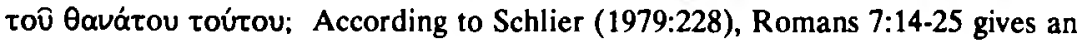
analysis of man's existence - that is, man under sin. Man is condemned. (That is, if we take 'I' in verse 13ff as 'man'. Suurmond [1983:199] argues that it refers, rather, to the 'believers', of whom Paul is one.) Man is purchased as a slave of $\sin (\mathrm{Rm}$ 7:14), he is unspiritual, belonging to the flesh ( $\mathrm{Rm} 7: 14)$, he does what he detests ( $\mathrm{Rm} 7: 15-16)$, there is nothing good in him $(\mathrm{Rm} 7: 18)$. In fact, man is a miserable 
creature ( $\mathrm{Rm}$ 7:24). This being the case, Byrne (1981:565) says that Romans 7:14. 25 demonstrates the moral 'impossibility' of man pleasing God.

However, this is not the last to be said about man's condition. There is another, a brighter side: the side initiated by God and caused by Christ and the Spirit. In the cry of frustration, there is hope, there is an answer, which we find in Romans 7:25a:

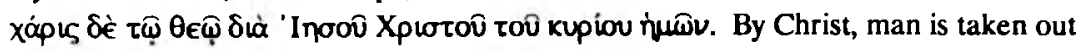
of his position of despair, and he is placed under a new rule, that is of the Spirit. In Romans 8:1ff, Paul goes on in describing what the life under the Spirit involves. In Chapter 8 we deal with the other side of the paradox of the Christian's life (Suurmond 1983:204). Wilckens (1980:118) also sees Romans 8 as the other side of the paradox:

Was daß Verhältnis zum Voranstehenden betrifft, so ist zunächst eindeutig, daß in 8,1ff nunmehr der zweite Teil der These 7,5f entfaltet wird: 7,6. Während es in 7,7-24 in Auslegung von 7,5 und das Thema der Gefangenschaft des Sünders unter dem 'Gesetz der Sünde' [7,23] ging, geht es jetzt um die Befreiung von diesem [8,2], durch die den Christen die Erfüllung des Gesetzes als 'Dienst im neuen Machtbereich des Geistes' $[7,6]$ ermöglicht worden ist $[8,4]$.

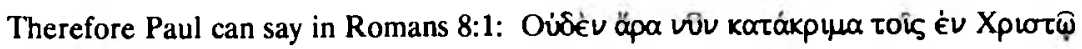
'Inoov'

Coetzer (1981:181), in doing a structural analysis of Romans 8, summarises the content of the pericope $\mathrm{Rm}$ 8:1-17 as follows: 'The pneuma enables those who have been liberated by Christ to live truly and to realize their sonship.' It is further divided into three clusters, namely: (1) Romans 8:1-4 - 'Christ has liberated us', (2) 8:513 - 'The pneuma enables us to be able to live' and (3) 8:14-17 - 'Through the pneuma the believer's sonship is realized.' As far as the first cluster is concerned, there is a close relation between Christ and the pneuma. The Spirit is closely bound to the mission of Christ. What was previously impossible to do, namely to fulfil the law, is made possible by the death and resurrection of Christ. Suurmond (1983:208), in the context of Romans 8:9-11 goes as far as to say that Paul identifies the Spirit with Christ. Whether this is really the case is hard to say, but to Paul the terms 'in Christ' and 'in the Spirit' are interchangeable (Mohrlang 1984:116; Heron 1983:46). Therefore in this context 'being in Christ' also means 'being in the Spirit'. This means standing under the rule of the Spirit which has certain consequences, spelled

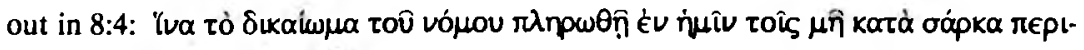

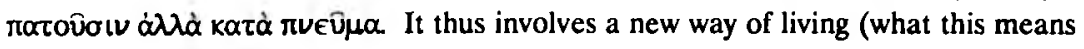


we will see later). Says Combrink (1969:48): 'In dié verband is Rom. 8:4 'n uiters belangrike vers omdat hier die nuwe sedelikheid in verband gebring word met regverdiging. Die passief $\pi \lambda$ npw die Gees waardeur dit alles tot wetsvervulling kom.'

Verses 5-13 briefly spell out the consequences of not being 'in Christ' or 'in the Spirit'. It means falling back to the sarx, consequently falling into death, which is the result of the sarx. On the other hand, living in the Spirit means true life, and allowing the Spirit to be the norm in the true life. By this the law is internalised. It is those who are walking according to the Spirit who fulfil the law.

Being 'in the Spirit' also has some benefits for the believer. This is what Romans 8:14-17 is about. It involves sonship through the Spirit (8:14) and being children of God, we are allowed to call him ' $A b b a$ ', which indicates a very close relationship with God. This in turn means that believers can inherit the same suffering and glory that there is in Christ. They can have part in his suffering and glory.

The relationship between Romans 8:1-17 and the ethics of Paul is worked out by Mohrlang (1984:115-123) in particular. He states that, in the ethical realm, it is the Spirit of God that makes moral living possible (see also Byrne 1981:557, who calls 8:1-13 an 'ethical exursus' in which Paul declares that, through the influence of the Spirit, the previous ethical 'impossibility' [ $R m$ 7:7-25] is converted into a ethical possibility). True goodness, as Mohrlang puts it, can only be attained by living in Christ 'according to the spirit' (Rm 8:I.4ff; Gl 5:16-25). On the role of the Spirit, Mohrlang goes on to state that there cannot be a relationship with Christ apart from the Spirit (Rm 8:9):

Thus, in Paul's thinking, the pronouncement of Suxalooium forensically cannot be considered apart from the experience of $\delta$ ukaooún ethically i.e. the power of $\delta$ tkalooúm must be realized in the believer's life - and that is possible only through the work of the Spirit [cf 2 Cor. 3:8f]. At the heart of Pauline ethics, then, lies the concept of the Spirit as the primary driving force behind morality and ethics.

It is only to the extent that the Christian lives 'according to the Spirit' that he actual-

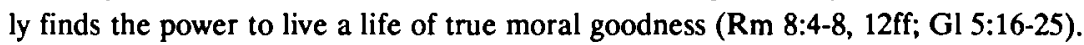
But it is also true that, though the full power of the Spirit is available for ethical living, it is still up to the believer whether he wants to draw on it or not. The Spirit's work is neither automatic nor irresistible. Though Paul grounded his ethics fundamentally in the concept of grace and he was thoroughly dependent on the initiating and energising work of God himself in man, in no way does this negate or lessen the 
responsibility of the individual to respond to it. Indeed, it is emphasised throughout that the full implementation of God's grace in the believer's life depends on his response to it.

It is thus clear that the Spirit opens up the possibility for moral living and yet the believer still has a responsibility relating to the Spirit, and thus must choose to be ethically involved. In this regard Beker (1980:289) calls for ethical seriousness. Believers are to challenge the power of death in the world. 'They must show in the midst of - and in solidarity with - this world the new life that is God's design for the future of the created order.' But, what does this 'new life' mean?

What everything up to this point boils down to is that 'in the Spirit' everything is new, we have entered a 'new life' or a 'new creation' (as it is called by some exponents of ecumenical pneumatology). But how widely should we interpret this new life?

Being in the Spirit or, being in the new life caused by the Spirit could be seen as the believer being a totally new 'being'. He is not a superhuman being, he stays human, but with a new 'inner self', a new existence. According to Du Plessis (1969: 16), the Spirit is not merely the power of the new life in the moral sense of the word, but the renewal of the entire existence of man, in all the functions and possibilities of his existence. Knoch (1975:64) quotes 2 Corinthians 5:17ff in explaining that newness depends on Christ: 'Wenn Iemand in Christus ist, dann ist er eine neue Schöpfung: das Alte ist vergangen, Neues ist geworden. Das alles kommt von Gott, der uns durch Christus mit sich versöhnt hat.' Between the old and the new there is a radical difference. Beker (1980:288) calls the transfer from the 'body of sin' or 'flesh' to the Spirit, a 'radical discontinuity between the "old man" [palaios anthropos Rom. 6:6] and the "new creation" [kaine ktisis, Gal. 6:15; 2 Cor. 5:17; cf. Rom. 6:4]'. Where sin and the 'flesh' previously took control over man, the Spirit does it now. Man lives under a new realm, a new 'power sphere'. As Schütz (1985:165) says: 'Das Sein in Christus beinhaltet zugleich das Sein des Geistes in uns. Dahinter steht die Vorstellung von einer Sphare, in der der Glaubende gleichsam lebt, von einer Kraft, in deren Bereich der Mensch getreten ist, die sein Sein, Denken und Verhalten beeinflußt.' The Spirit is a new reality that is established by Christ, it is a whole new atmosphere within which 'life in Christ' is lived. The power structure of the flesh has been replaced by the power structure of the Spirit. Now one is no longer captive of the law of sin in one's members but is subject to a new order, that of the Spirit' (Keck 1980:52). Thus, new life means freedom from sin.

The 'new creation' is summarised by Paul in the term $\dot{\epsilon} \lambda \in U \theta \epsilon \rho i a$ This freedom

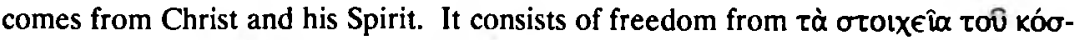

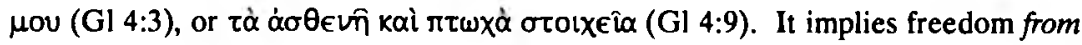


the bondage of sin, the law of Moses and the 'flesh'. At the same time it means standing under a new master, that is the Spirit. Therefore, freedom from sin simultaneously means freedom for the Spirit. Freedom for the Spirit consists of walking by the Spirit'. Newness is a 'Spirit-controlled existence' (see Lull 1980:130). Thus the Spirit-controlled life, leads to a Spirit-controlled way of life, a new way of living, a new 'ethical life'. In this sense the ecumenical pneumatology is correct in seeing the Spirit as the agent of ethical responsibility.

But it still remains an open question as to how widely we have to interpret the so-called 'new creation'. We have already seen that in ecumenical pneumatology it is evaluated so widely, as to include the whole creation, that is the earth, animals, and the whole ecosystem. Renewal implies that man, moved by the Holy Spirit, actively is involved in making the whole world new. Romans 8:18ff is especially used to substantiate this point (see Moltmann 1990:98; Schweizer 1989:405; Tamez 1989:446). Under the so-called 'Integrity of creation' everything is placed on the same level as mankind; God's salvation not only means saving humans, but also animals, in fact the whole universe. Du Plessis (1969:16) holds the view that '[i]t also means renewal of the universe and Christ governing the universe and history'. Suurmond (1983:213) declares: 'The whole section 8:13-30 centres on the hope which touches not only Christians, but the whole of mankind and even the entire creation' (see also Wilckens 1980:151). Paul indicates in Romans 8:18 and 19 that all crea-

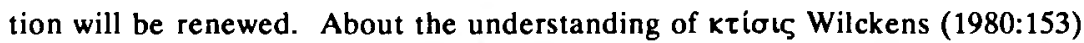
states: 'Man wird darum dem Text Röm 8,19-22 m.E. nur gerecht, wenn man kríolç - jedenfalls primär - im Sinn der gesamten außermenschlichen Schöpfung versteht' (see also Kehnscherper 1978:236). Thus, in the context of Romans 8, the Holy Spirit is indeed involved in the renewal of the whole created order.

Yet there is a substantial difference between the renewal of creation and that of the (human) believer. There is a difference in how the Spirit is involved in creation (that is, the created order), and in the believer (or man). The whole created order is still to be renewed, believers have already been renewed. The creation has not yet

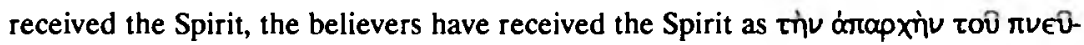

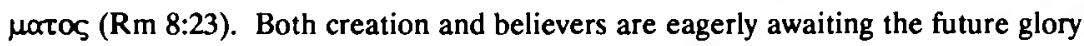
to come, yet the believers have already received some of the glory in the Spirit: 'It is not man who gives a first portion to God, but the pneûma is God's aparche to man. Man is the recipient and his gift is already presently experienced' (Coetzer 1981: 188). The difference between the groaning of creation and that of believers is summed up by Hahn (1986:84) as follows: 
The progression of thought moves from the groaning of creation to the groaning of believers. In v. 19 creation is said to be eagerly expecting the revelation of the sons of God. In v. 23 believers eagerly expect huiothesia as they groan. The first fruit of the Spirit characterizes the groaning of the believers in a way that has no parallel in creation.

Therefore the suffering and groaning in creation is used by Paul as a sign of future renewal in creation. Indeed the groaning calls for renewal. This renewal starts primarily within the believer who has a responsibility towards creation. But we should be careful not to be over optimistic or over idealistic about the creation, which will certainly be renewed by our own efforts, but which still awaits divine future intervention (from Paul's viewpoint). Therefore the ecological crisis certainly calls for our attention but, in Paul's view, it could also be an indication or sign of the futileness, the $\mu$ ótalos (Rm 8:20), of this world that awaits God's new creation.

We still have to answer one question: What are the implications of the new life for the believer? We have stated above that new life also consists of new 'ethical life'. But how is this 'ethical life' to be filled? Galatians 5:13-26 might give us some light on this question because Paul uses the same arguments as in Romans, but he spells out more clearly what he understands under the 'practical' implications of the

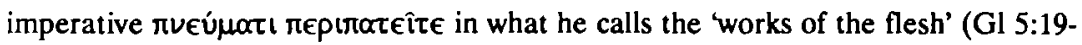
21), against the 'fruits of the Spirit' ( $\mathrm{Gl}$ 5:22-24). Clearly, being in the Spirit de-

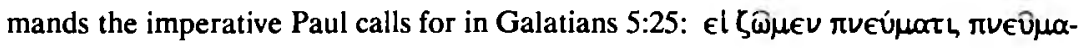
$\tau \iota$ kai $\sigma \tau o เ x \bar{\omega} \mu \in v$. But before one is able to carry out the intentions of the Spirit, one should first give up living in the desires of the flesh, and by faith accept life in the sphere of the Spirit (by means of which one can perceive the intentions of the

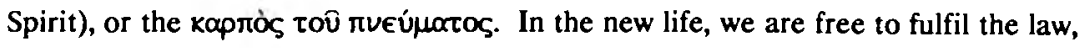
by abiding in the 'fruits of the Spirit'.

But, how are these 'works of the flesh' and 'fruits of the Spirit' to be understood? Are these 'catalogues of vice and virtue' still valid for today, and if so, how? What does Paul for instance mean by ropveía (to take only one vice), and áý́rn (to take only one virtue)? ropveía could be taken to mean 'prostitution', but also methaphorically as 'unfaithfulness or disloyalty against God' (Mußner 1977:381). ay $\alpha^{\prime} m_{n}$ in turn, could refer to neighbourly love or love to God, but exactly which is correct is not clear. Therefore, even these vices and virtues are not clear. It depends on the situation in which the words are used, like most of the vices and virtues in the New Testament. It is not clear, either, how we are to take these vices and virtues today. Moreover, as Houlden (1973:121) states, the New Testament 
writers 'wrote for their own reasons in their own circumstances, unaware of the future role of their work'. This view is also shared by Strecker (1978:139): 'Die ethische Weisung führt in eine konkrete Situation hinein, auf die sie antwortet und in der sie wahrgenommen werden soll.' The New Testament writers addressed specific occasions and situations, and these can only be understood in their historical and sociological context (see Schrage 1988:5; Houlden 1973:121). Thus Galatians 5:13-26 was written for a specific situation, which would take us too long to determine here. But it is quite obvious that the circumstances then and now are different. This leads Scroggs (1984:89) to concur with Houlden that the teaching of the New Testament is timebound and speaks to its own age and situation, not our own. This has led Sanders (1975:129) to the conclusion that the New Testament is irrelevant to contemporary ethical discussion (see also Scroggs 1984:87). As Sanders (1975:129) says: '...throw out the New Testament as an aid to ethics once and for all.' But this is not the way that we want to go.

Although Houlden (1973:120) holds to it that the New Testament is timebound, he does not completely rule out its relevance for contemporary ethics, as Sanders does. Because the New Testament has played a significant role in Christian tradition over the centuries it still has to be taken into account. Moral conduct derived from the New Testament is still important because of the 'new life' in the Spirit and because of the indicative in Christ. 'A certain performance is...asked not in order to enter a future kingdom but because of that kingdom' (Scroggs 1984:91).

In this moral conduct, the New Testament, and the vices and virtues, as found for example in Galatians 5:13-26, could function not as handbook, but as 'point of reference' for making moral decisions (see Schrage 1988:2). In this, the New Testament is not simply and directly repeated, but carefully taken up in a complex process of re-application and re-interpretation in the present-day context. In this re-application, new circumstances and situations have to be realised, present-day philosophy has to be dealt with and even other human sciences should be considered carefully. The philosophy of the day was used in New Testament times, and could certainly be used again. Paul used the catalogues of moral conduct of the Old Testament, but also the catalogues of vice and virtue in Hellenistic and late Judaic literature ('hellenistischen und spätjüdischen Literatur') in Galatians 5:13-26 (see Bultmann 1967:51; Mußner 1977:380). These vices and virtues were appropriate for the time, and were used by the popular philosophers of that time. Therefore we could say that, in order to apply the 'new life in the Spirit' to his time, Paul used known material, taken from the popular philosophers. Thus modern thought is needed to enable us to re-interpret the New Testament and apply the 'new life in the Spirit' today. In this, holism 
and ecumenical pneumatology can be useful, and experienced as exciting, to arrive at present day re-interpretation of ethical involvement.

According to Hübner (1989:333), the Christians, who are in the Spirit, are the new creation. Those who walk in the Spirit (cf Gl 5:25 which is the ethical dimension of pneumatology) are the new creation. The Christians being the new creation has lead Outler (1989:371) to state that there are also new horizons of inquiry to be sought in current ventures in the re-uniting of pneumatology with Christian social action. He goes on: 'The biblical ethic is reflection upon God's passion for justice, mercy, peace and freedom.' It is the Spirit's office to teach us that God's rule of righteousness must still be honoured in every earthly circumstance. Outler (1989:371) proceeds:

\begin{abstract}
We may now need to speak less of 'man's [horrendous] inhumanity to man', less of human sacrilege upon the fragile planet on its way to becoming less habitable, less even of our faltering faith in technology and technocrats, than of the spiritual energy that is required of Christian 'martyrdom' in Christian crusades for humanity. Here the whole creation groans, less for knowledge and high resolve than for a revived spirit of human dignity, as the remains of God's own image in humanity. There is a Christian imperative to act out of a compassion that will not abide human indignity. Here, too, pneumatology holds a vital clue to the problems of Christian motivations for social action.
\end{abstract}

We therefore have to be orientated towards the world, because the crisis of the world is also our crisis for, as 'flesh and blood', that is as part of this world, we will be destroyed if the world is destroyed (see Moltmann 1990:102).

Holism and ecumenical pneumatology, however, have their limitations; in fact they hold an alarming danger as well.

\title{
4.2 An alarming danger
}

In evaluating any interpretation of the work of the Holy Spirit, we have to allow for a certain amount of subjectivity on the part of the interpreter, which makes evaluation difficult. Dunn (1972:8) reasons that 'the Spirit of the New Testament period was first and foremost an experience - an experience almost tangible in quality'. He quotes Eduard Schweizer in saying: 'Long before the Spirit was an article of doctrine it/he was a fact in the experience of the primitive Church.' This view is shared by Knoch (1975:16-17) in his reflection on the experience of the Spirit by Paul: 'Was Paulus in seinen Schreiben über den Heiligen Geist sagt, stammt aus eigener Erfah- 
rung....' Being an experience, even today, opens up a variety of viewpoints, including a holistic interpretation of the Spirit. Moreover, there is some ambiguity in Paul's experience of the Spirit. We have to realise that 'for Paul there is nothing distinctively Christian in charismatic phenomena as such' (Dunn 1975:302). Healings and wonders, dreams, epiphanies and visionary experiences, ecstasy and inspired utterances, were all well-known religious experiences that also occurred outside early Christianity. Thus there was great freedom in experiencing the Spirit, which had in it the danger of misuse (see Knoch 1985:185). Therefore, there was need for some control: '...the danger of charismatic experience and the need for controls on charismata within the Christian community is confirmed and underlined' (Dunn 1975:307). According to Dunn (1982:12), and we could agree with him, '[t]he NT shows us not only the importance of prophecy for a living Christianity but also the danger of false prophecy'. This presents the key to the evaluation of ecumenical pneumatology.

Early Christianity knew about the ecstatic, but also recognised the need for checks and balances (see Dunn 1982:13). But how can we recognise where the Spirit of God is at work? What, then, are the marks by which we could distinguish the activities of the Spirit in order to know what is true or false? To answer these questions, 1 Corinthians 12:1-11 (wv 3 and 7 in particular) might be of help.

1 Corinthians 12:3 should be understood against the background of the existence of the phenomena called 'enthusiasm' which goes hand in hand with ecstatic experiences like speaking in tongues and predicting the future. Paul acknowledges these phenomena, as he himself also had an ecstatic experience on his way to Damascus (see 2 Cor 12:1ff). What made this experience distinctive, however, was the confession 'Jesus is the Lord' (1 Cor 12:3). 'Wahre Wirkung des Geistes ist...die Anerkennung des Kyrios in allen Dingen...' (Wolff 1982:101; see also Bornkamm 1983:188). Whatever inspiration denies the kerygma of Jesus's death and resurrection, declares by that very fact its source to be other than the Spirit. This means that, in Paul's view, the Spirit has been limited or has limited himself to the yardstick of Jesus (see Dunn 1975:319, 324). There are two other criteria to distinguish the Spirit, namely: Does it express or engender love (see 1 Cor 13) and does it benefit and build up the community? (See 1 Cor 12:7; 1 Cor 14; cf Wolff 1982:101; Dunn 1982:14; Knoch 1975:186-193.) For the purpose of this paper, we shall not go into this any deeper. The first and foremost criterion of the Spirit still remains the confession 'Jesus is Lord'. This is, as Dunn (1982:14) puts it, still a valuable yardstick, even for today. He says: 'Christianity today, as in every day, cannot escape the responsibility for evaluating the source and the relevance or value of whatever is offered as truth for our time, of whatever claims to express the will of God now.' Therefore, although difficult and open to a variety of views, any experience of the Spirit 
has to be evaluated in the light of the Christ-event and the Christ-confession. This is also the case with ecumenical pneumatology.

The danger of the view of the Spirit as agent of ethical responsibility in ecumenical terms is that we can get so preoccupied with social upliftment or the ecological crisis that this can lead to what Schrage (1988:1) calls 'activism', and the consequent loss of the Christ-event and Christ-confession. Of course this is not always true. There are a number of contributors who hold that there is a close connection between Christ and the Spirit (see Hübner 1989:324; Clapsis 1989:344; Schweizer 1989:408. It is interesting to note that they all reason strongly from the New Testament text.) Yet, the danger still remains. A warning comes even from within the ecumenical circle, in the words of Breck (1990:115):

In current ecumenical dialogue, there is a certain danger...Under the influence of various charismatic and liberation movements, a temptation exists to emphasize the role of the Spirit in such a way as to separate him from the work of Christ and consequently from the tri-unity of the Godhead...[I]n the present day, the danger is that a renewed awareness of the presence and the power of the Spirit...will lead to a pneumatology devoid of a Christological foundation.

Breck (1990:120) concludes:

Consequently the invocation, 'Come, Holy Spirit - renew the whole creation', cannot have as its primary intention some proximate end such as social and political justice, ecological restoration, or even individual spiritual awakening. Vital as these ends are [see above - E J $V]$ preoccupation with them too easily diverts our attention from the real issue... (my italics).

The real issue, with regard to the Spirit and ethical responsibility, still is, and will always be, the confession 'Jesus is Lord'. If the prime and sole intention of the Spirit as agent is to restore and resolve social and ecological issues, Christ becomes irrelevant. Any pneumatology, without its christological foundation, would cause everything - however subjective, vague and uncontrollable - to be seen as 'the Spirit' or the 'new life'. Then the Spirit becomes a mere principle for the so-called 'debate of religious pluralism', a debàte between different religions (see Raiser 1989:384; Ukpong 1989:422). The Spirit then is merely a principle by means of which to bring people of different religions together in dialogue to 'save the world from extinction'. 
This in turn boils down to the fact that man wants to save himself (without Christ), which runs contrary to the Pauline view of justification through Christ and by faith.

It is clear that, for Paul, God has acted in a way totally different from what humans would imagine. Man, from the days of the pious Jews in Paul's time up to the present, has wanted to establish his own righteousness by fulfilling the demands of the law. But, after becoming a Christian, Paul learned that it was not possible to create his own righteousness by complying by the law. 'God has revealed himself as the one who acts justly and declares righteous, without his demanding works of the law or bringing them into consideration' (Kümmel 1974:197). God's righteousness has become manifest through faith in Jesus Christ for all who believe (see Rm 3:2122; 26-27). It is evident that, to Paul, justification is a saving act of God through Christ, which is given to those who believe in Christ. The question is whether this faith in Christ is adequate, or should it be supplemented by whatever means available, whether by the law or circumcision (as in Paul's time), or perhaps by social or environmental involvement (as in modern times).

Arguing from Galatians 5:2-12, Keck (1979:86) says that, for Paul, faith in Christ certainly is adequate, and need not be supplemented: 'To live by the law, to meet the obligations in order to relate rightly to God [to do "the works of the law"], is not to live by sheer trust in God's grace; in this case a right relation to God is not received as a gift, but as just reward.' The Galatians misunderstood a few things, as Keck (1979:87) mentions further:

(a) They thought that circumcision would enhance and perfect what they already had...(b) They thought that accepting a requirement for perfection did not conflict with the mode of trust/faith. In fact, however, they failed to realize that meeting requirements and sheer trust in God do not mix. (c) They thought they could accept circumcision and revert to calendrical observances without jeopardizing the meaning of Christ. In fact, however, they failed to realize that doing so annulled the whole meaning of the Christ-event...In short, by trying to improve sheer trust/faith, by refusing to believe that trust in God was adequate for a right salvic relation to God and to the self, the Galatians gained religiosity - but forfeited the gospel.

Theologically, the demand for circumcision or 'meeting the requirements of the law' can take many forms. It appears whenever one thinks along these lines: 'Faith in Christ is fine as far as it goes, but your relation to God is not really right and your salvation not adequate unless...' (see Keck 1979:89). It does not matter how the sen- 
tence is completed. 'Whenever such fine print is introduced to qualify trust/faith, there is "circumcision" and Paul's defence of the adequacy of trust/faith is necessary' (Keck 1979:89). In as far as this is happening in the pneumatology of the ecumenics, in which the danger exists that Christ becomes irrelevant and faith in Christ inadequate, and in as much as it has to be supplemented by anything else like resolving the crisis in the world, the situation is experienced as extremely alarming, because to Paul, Christ can never be replaced or supplemented.

\section{CONCLUSION}

The Spirit indeed moves man to the new life. He brings about change inside the believer. This new life in the Spirit (or 'in Christ'), or the so-called 'indicative' of the new life, should cause an awareness in the believer of this 'imperative' that will lead to a new way of living. This new way of living is not to achieve the kingdom of God, but the result of it. On how this new way of living is to be achieved, Paul mentioned for example Galatians 5:13-26. But this passage, like others can not be taken over exactly as it is for the situation of today. It has to be re-applied and reinterpreted. In this, holism and ecumenical pneumatology is experienced as a helpful, modern paradigm, a useful tool for re-interpretation.

Holistic thought is correct in seeing that the Newtonian-Cartesian paradigm has alienated man from the earth. This has caused the crisis in which we find ourselves. Ecumenical pneumatology has correctly taken over this thought in as far as the Spirit moves us to realise that we do have an ethical responsibility towards our fellowman, but also towards the earth. This is confirmed by Romans 8:1-4. The Holy Spirit provides us with a sense of belonging: We are not that much alienated that our lives are totally meaningless and senseless. By the Spirit, we belong to God; we are his children ( $R m$ 8:15). But God has placed us (as his children) in this world. Therefore we also have a place on earth, which imposes on us a responsibility for dealing with the social, economical, political and ecological issues of our day.

On the other hand, ecumenical pneumatology, in as far as it stimulates social, environmental and ecological involvement in resolving the present-day crisis, could lead to our making Christ irrelevant, and it could lead to making the above-mentioned involvement supplementary to faith and trust in Christ. This is experienced as alarming because it is counter to the core confession: 'Jesus is Lord' ( 1 Cor 12:3). 
Works cited

Assmann, H 1990. JPIC and the 'warm God' of the global market. The Ecumenical Review 42, 45-60.

Beker, J C 1980. Paul the apostle: The triumph of God in life and thought. Edinburgh: T \& T Clark.

Bobrinskoy, B 1989. The Holy Spirit - in the Bible and the church. The Ecumenical Review 41, 357-362.

Boelema, J 1987. Op zoek naar holisme (II). Profeet van het holisme: Heil uit het verre oosten? Getrouw 1, 4-6.

Bohm, D 1986. The implicate order: A new approach to the nature of reality, in Schindler, D L (ed), Beyond mechanism: The universe in recent physics and Catholic thought, 13-37. Lanham: University Press of America.

Bornkamm, G 1983. Paulus. 5. Aufl. Stuttgart: Kohlhammer.

Breck, J 1990. 'The lord is the Spirit': An essay in christological pneumatology. The Ecumenical Review 42, 114-121.

Bultmann, R [1924] 1967. Das Problem der Ethik bei Paulus, in Dinkler, E (Hrsg), Exegetica: Aufsätze zur Erforschung des Neuen Testaments, 36-54. Tübingen: Mohr.

Byrne, B 1981. Living out the righteousness of God: The contribution of Rom. 6:18:13 to an understanding of Paul's ethical presuppositions. $C B Q 43,557-581$.

Capra, F 1983. The turning point. Science, society and the rising culture. London: Flamingo. (Fontana Paperbacks.)

-- 1989. Uncommon wisdom. Conversations with remarkable people. London: Flamingo. (Fontana Paperbacks.)

Clapsis, E 1989. The Holy Spirit in the church. The Ecumenical Review 41, 339-347.

Coetzer, W C 1981. The Holy Spirit and the eschatological view in Romans 8 . Neotestamentica 15, 180-198.

Combrink, H J B 1969. Die verhouding pneuma-dunamis. Neotestamentica 3, 45-51.

Dunn, J D G 1972. Rediscovering the Spirit. ET 84, 7-12.

--- 1975. Jesus and the Spirit: $A$ study of the religious and charismatic experience of Jesus and the first Christians as reflected in the New Testament. London: SCM.

-- 1982. Rediscovering the Spirit (2). ET 94, 9-18.

Du Plessis, P J 1969. The concept of pneuma in the theology of Paul. Neotestamentica 3, 9-20.

Flesseman-van Leer, E 1989. 'I believe in the Holy Spirit.' The Ecumenical Review 41, 348-356.

Hahn, R L 1986. Pneumatology in Romans 8: Its historical and theological context. Wesleyan Theological Joumal 21, 74-90. 
Hefner, P 1987. Freedom in evolutionary perspective, in Mortensen, V \& Sorensen, R C (eds), Free will and determinism. Aarhus: University Press.

--- 1988. Theology's truth and scientific formulation, in Mouton, Van Aarde \& Vorster 1988:11-28.

Heron, A I C 1983. The Holy Spirit. Philadelphia: Westminster.

Houlden, J L 1973. Ethics and the New Testament. London: Mowbrays.

Hübner, H 1989. The Holy Spirit in Holy Scripture. The Ecumenical Review 41, 324-338.

Keck, L E 1979. Paul and his letters. Philadelphia: Fortress.

-.- 1980. The law and 'The law of sin and death' (Rom 8:1-4): Refections on the Spirit and ethics in Paul, in Crenshaw, J L \& Sandmel, S (eds), The divine helmsman: Studies on God's control of human events. Presented to Lou H Silberman, 41-57. New York: KTAV.

Kehnscherper, G 1978. Romans 8:19 - On Pauline belief and creation. Studia Biblica 3, 233-248.

Knoch, O 1975. Der Geist Gottes und der neue Mensch. Stuttgart: Katholisches Bibelwerk.

Kümmel, W G 1974. The theology of the New Testament: According to its major witnesses: Jesus-Paul-John. London: SCM.

Lechte, R E 1990. Partnerships for ecological wellbeing. The Ecumenical Review 42, 157-161.

Lemopoulos, G 1989. Come, Holy Spirit. The Ecumenical Review 41, 461-467.

Lull, D J 1980. The Spirit in Galatia: Paul's interpretation of pneuma as divine power. Chico: Scholars Press. (SBL Dissertation Series 49.)

Martin, J P 1987. Towards a post-critical paradigm. NTS 33, 370-385.

Matsoukas, N 1989. The economy of the Holy Spirit: The standpoint of orthodox theology. The Ecumenical Review 41, 398-405.

Mohrlang, R 1984. Matthew and Paul. A comparison of ethical perspectives. Cambridge: Cambridge University Press.

Moltmann, J 1990. The scope of renewal in the Spirit. The Ecumenical Review 42, 98-106.

Mouton, J \& Pauw, J C 1988. Foundationalism and fundamentalism: A critique, in Mouton, Van Aarde \& Vorster 1988:176-186.

Mouton, J, Van Aarde A G \& Vorster, W S (eds) 1988. Paradigms and progress in theology. Pretoria: HSRC. (HSRC Studies in Research Methodology 5.)

Mußner, F 1977. Der Galaterbrief. 3. Aufl. Freiburg: Herder. (HThK IX.)

Osei-Bonsu, J 1989. The Spirit as agent of renewal: The New Testament testimony. The Ecumenical Review 41, 454-460. 
Outler, A C 1989. Pneumatology as an ecumenical frontier. The Ecumenical Review 41, 363-374.

Preston, R 1989. Humanity, nature and the integrity of creation. The Ecumenical Review 41, 552-563.

Raiser, K 1989. The Holy Spirit in modern ecumenical thought. The Ecumenical Review 41, 375-387.

Rosato, P J 1989. The mission of the Spirit within and beyond the church. The Ecumenical Review 41, 385-397.

Sanders, J T 1975. Ethics in the New Testament: Change and development. Philadelphia: Fortress.

Schaeffer, J 1990. The liberation of creation. The Ecumenical Review 42, 61-67.

Schlier, H 1979. Der Römerbrief. 2. Aufl. Freiburg: Herder. (HThK VI.)

Schoeman, M J 1990. Holisme: Die herowering van 'n ou wysheid in 'n moderne konteks. HTS 46, 267-292.

Schrage, W 1988. The ethics of the New Testament. Philadelphia: Fortress.

Schütz, C 1985. Einführung in die Pneumatologie. Darmstadt: Wissenschaftliche Buchgesellschaft.

Schweizer, E 1980. The Holy Spirit. London: SCM.

--- 1989. On distinguishing between spirits. The Ecumenical Review 41, 406-415.

Scroggs, R 1984. The New Testament and ethics: How do we get from there to here? Perspectives in Religious Studies 11, 77-93.

Strecker, G 1978. Strukturen einer neutestamenlichen Ethik. ZThK 75, 117-146.

Smuts, J C [1926] 1987. Holism and evolution. Cape Town: N \& S Press.

Suurmond, J 1983. The ethical influence of the Spirit of God: An exegetical and theological study with special reference to I Corinthians, Romans 7:14-8:30, and the Johannine literature. Ann Arbor: University Microfilms International.

Tamez, E 1989. Now no condemnation: A meditation on Romans 8. The Ecumenical Review 41, 446-453.

Tinker, G E 1989. The integrity of creation: Restoring the trinitarian balance. The Ecumenical Review 41, 527-536.

Ukpong, J S 1989. Pluralism and the problem of the discernment of spirits. The Ecumenical Review 41, 416-425.

Van Aarde, A G 1990. Holisme as 'n postmodernistiese filosofie in 'n teologiese lig. HTS 46, 293-311.

Van Arkel, J T De Jongh 1988. Theology beyond Newton: A quantum leap, in Mouton, Van Aarde \& Vorster 1988:223-238.

Vischer, L 1990. Giver of life - sustain your creation! The Ecumenical Review 42, 143-149. 
Wilckens, U. 1980. Der Brief an die Römer. 2. Teilband: Röm 6-11. Zürich: Benziger Verlag. (EKK VI/2.)

Wilkenson, L 1987. New Age, new consciousness, and new creation, in GrandbergMichaelson, W (ed), Tendering the garden: Essays on the Gospel and the earth, 629. Grand Rapids: Eerdmanns.

Wolff, C 1982. Der erste Brief des Paulus an die Korinther. Zweiter Teil: Auslegung der Kapitel 8-16. Berlin: Evangelische Verlagsanstalt. (ThHK VII/2.) 